\title{
Extracellular Heat Shock Proteins: Alarmins for the Host Immune System
}

\author{
John S. Giuliano Jr, ${ }^{1}$, Patrick M. Lahni ${ }^{2}$, Hector R. Wong ${ }^{2,3}$ and Derek S. Wheeler*,2,3 \\ ${ }^{I}$ Division of Critical Care Medicine, Yale-New Haven Children's Hospital; Department of Pediatrics, Yale University \\ School of Medicine; New Haven, CT, USA \\ ${ }^{2}$ Division of Critical Care Medicine, Cincinnati Children's Hospital, USA \\ ${ }^{3}$ Department of Pediatrics, University of Cincinnati; Cincinnati, OH, USA
}

\begin{abstract}
Heat shock proteins (HSPs) are molecular chaperones that facilitate the proper folding and assembly of nascent polypeptides and assist in the refolding and stabilization of damaged polypeptides. Through these largely intracellular functions, the HSPs maintain homeostasis and assure cell survival. However, a growing body of literature suggests that HSPs have important effects in the extracellular environment as well. Extracellular HSPs are released from damaged or stressed cells and appear to act as local "danger signals" that activate stress response programs in surrounding cells. Importantly, extracellular HSPs have been shown to activate the host innate and adaptive immune response. With this in mind, extracellular HSPs are commonly included in a growing list of a family of proteins known as danger-associated molecular patterns (DAMPs) or alarmins, which trigger an immune response to tissue injury, such as may occur with trauma, ischemia-reperfusion injury, oxidative stress, etc. Extracellular HSPs, including Hsp72 (HSPA), Hsp27 (HSPB1), Hsp90 (HSPC), Hsp60 (HSPD), and Chaperonin/Hsp10 (HSPE) are especially attractrive candidates for DAMPs or alarmins which may be particularly relevant in the pathophysiology of the sepsis syndrome.
\end{abstract}

Keywords: Heat shock proteins (HSPs), danger-associated molecular patterns (DAMPs), Extracellular HSPs, polypeptides.

\section{INTRODUCTION}

Virtually all cells respond to stress through the activation of primitive, evolutionarily conserved genetic programs that maintain homeostasis and assure survival. Stress adaptation (also known in the literature as tolerance, desensitization, conditioning, or reprogramming) is a common paradigm found throughout nature in which a primary exposure of a cell to a stressful stimulus results in an adaptive (frequently protective) response, such that a second exposure to the same stimulus produces a minimal response. More importantly, this adaptive response is not unique to the original stimulus, in that exposure to a different stressful stimulus is also associated with a minimal response. This particular phenomenon is often called cross-tolerance or crossadaptation [1-2]. The heat shock response is one of the more commonly described forms of stress adaptation and was first described nearly 50 years ago [3-4]. The heat shock response, also frequently referred to simply as the stress response, is an ancient, highly conserved, endogenous cellular defense mechanism characterized by the rapid upregulation of a specific class of proteins known collectively as heat shock proteins (HSP) or stress proteins [5]. The structure, mode of regulation, and function of HSPs are phylogenetically conserved among different species, and HSPs have been isolated from virtually every class of living

\footnotetext{
*Address correspondence to this author at the Division of Critical Care Medicine, Pediatric Intensive Care Unit, Cincinnati Children's Hospital Medical Center, 3333 Burnet Avenue, Cincinnati, OH 45229-3039; Tel: (513) 636-4259; Fax: (513) 636-4267;

E-mail: Derek.wheeler@cchmc.org
}

organism to date, including both prokaryotes and eukaryotes. These proteins range in molecular weight from $7 \mathrm{kDa}$ to 110 $\mathrm{kDa}$ and have been found in virtually every part of the cell, including the nucleus, cytoplasm, and mitochondria [1-2, 67]. By convention, the HSPs are grouped and classified into families based upon their molecular weight, e.g. Hsp70 refers to the $70 \mathrm{kDa}$ family of HSPs, though the nomenclature of human HSPs has recently been standardized (Table 1) [8]. Herein, we will refer to both the traditional and standardized nomenclature in order to avoid confusion. There are also an increasing number of proteins that have well defined cellular functions not directly related to cellular stress, but have been demonstrated to be expressed in response to heat shock and other cellular stresses [9-10]. These so-called moonlighting proteins include ubiquitin [1112]; heme oxygenase [13]; inhibitor of $\kappa \mathrm{B}, \operatorname{I\kappa B} \alpha$ [14]; endothelial nitric oxide synthase, eNOS [15]; and mitogenactivated protein kinase (MAPK) phosphatase-1 (MKP-1) [16].

The HSPs are generally thought to maintain cellular homeostasis by acting as molecular chaperones, facilitating the proper folding and assembly of nascent polypeptides and assisting in the refolding and stabilization of damaged peptides [6-7, 17]. Consistent with their function as molecular chaperones, HSPs have traditionally been considered to be exclusively intracellular proteins. However, not long after the HSPs were first discovered, Morton and colleagues [18] discovered a circulating immunosuppressive protein, termed early pregnancy factor (EPF), which was later found to be a mitochondrial HSP known as chaperonin (Cpn)/Hsp10 (HSPE) [19]. Later, Hightower and Guidon 
Table 1. Major Heat Shock Protein Families

\begin{tabular}{|c|c|c|c|c|}
\hline Name & $\begin{array}{c}\text { Size } \\
\text { (kDa) }\end{array}$ & Localization & Bacterial Homolog & Some Known and Possible Functions \\
\hline Ubiquitin & 8 & Cytosol/nucleus & - & Nonlysosomal degradation pathways \\
\hline $\begin{array}{l}\text { HSP } 27 \\
\text { (HSPB1) }\end{array}$ & 27 & Cytosol/nucleus & - & $\begin{array}{l}\text { Regulator of actin cytoskeleton; molecular } \\
\text { chaperone; cytoprotection }\end{array}$ \\
\hline Heme oxygenase & 32 & $\begin{array}{l}\text { Bound to ER, } \\
\text { extends to cytoplasm }\end{array}$ & - & $\begin{array}{l}\text { Degradation of heme to bilirubin; } \\
\text { resistance to oxidant stress }\end{array}$ \\
\hline HSP 47 & 47 & ER & - & Collagen chaperone \\
\hline $\begin{array}{l}\text { HSP } 60 \\
\text { (HSPD) }\end{array}$ & 60 & Mitochondria & Gro EL & Molecular chaperone \\
\hline \multirow[t]{2}{*}{$\begin{array}{l}\text { HSP } 70 \\
\text { (HSPA) }\end{array}$} & 72 & Cytosol/nucleus & Dna K & $\begin{array}{l}\text { Highly stress inducible; involved in } \\
\text { cytoprotection against diverse agents }\end{array}$ \\
\hline & 73 & Cytosol/nucleus & - & Constitutively expressed chaperone \\
\hline $\begin{array}{l}\text { HSP } 90 \\
\text { (HSPC) }\end{array}$ & 90 & Cytosol/nucleus & htpG & Regulation of steroid hormone activity \\
\hline HSP 110 & 110 & Nucleolus/cytosol & Clp family & Protects nucleoli from stress \\
\hline
\end{tabular}

[20] demonstrated that Hsp70 (HSPA) was released into the extracellular fluid by cultured rat embryo cells in response to thermal stress. Release of Hsp70 (HSPA) occurred in the absence of cell death and was not inhibited by either monensin or colchicine, suggesting that release occurred via a non-classical secretory pathway (see below). More importantly, release was inhibited when these proteins were synthesized in the presence of the lysine analogue aminoethyl cysteine, suggesting that proper folding of $\mathrm{Hsp} 70$ (HSPA) was necessary for secretion [20]. Since that time, there has been a virtual explosion of literature on the biology of extracellular HSPs. Perhaps even more intriguing is the relatively recent recognition that extracellular HSPs possess the ability to stimulate many cells of the innate and adaptive immune systems [21]. Herein, we will briefly review the current roles that extracellular HSPs play in both the innate and adaptive immune responses. We will focus primarily upon host-derived HSPs, rather than bacterial-derived HSPs. Moreover, we will focus primarily upon five specific families of HSPs - Hsp70 (HSPA), Hsp27 (HSPB1), Hsp90 (HSPC), Hsp60 (HSPD), and Hsp10 (HSPE) as the extracellular roles of these HSP families are the best characterized to date.

\section{DANGER SIGNALS, ALARMINS, AND DAMPS}

The host immune response has evolved over time to protect organisms from infection, injury, and subsequent death. Danger signals [22-24] are molecules that alert and activate the host immune response - these danger signals may come from either the internal or the external environments and activate cells of either the innate or adaptive immune response. External or exogenous danger signals have traditionally been called pathogen-associated molecular patterns (PAMPs) and include pathogen-derived proteins, nucleic acids, and lipids such as lipopolysaccharide (LPS), peptidoglycan, lipoteichoic acid, CpG DNA, and flagellin. These PAMPs are recognized by a surprisingly limited number of highly conserved pattern recognition receptors (PRRs), which include the Toll-like receptors (TLRs) and the nucleotide-binding oligomerization domain (NOD) receptors. Perhaps it is more than just a mere coincidence that these same PRR appear to recognize endogenous danger signals as well [25] - hence the term, danger-associated molecular pattern or DAMP [26]. Endogenous danger signals may be secreted by damaged cells or released rather non-specifically by necrotic cells to act in an autocrine, paracrine, or endocrine manner, thereby alerting the host to the presence of tissue injury. Oppenheim was the first to coin the term alarmin for these endogenous DAMPs [27]. In summary then, exogenous DAMPs (LPS, CpG DNA, etc) usually trigger an immune response to an infectious insult (e.g. bacteremia), while endogenous DAMPs or alarmins trigger an immune response to tissue injury, such as may occur with trauma, ischemia-reperfusion injury, oxidative stress, etc. Several candidate alarmins have been described, including high mobility group box 1 protein (HMGB1) [28-33], uric acid [34-39], and extracellular HSPs $[6,26,33,40-43]$, among others.

Several properties would suggest that extracellular HSPs are biologically plausible and likely candidates to serve as alarmins [44-46]. First, collectively, the HSPs are the most abundant intracellular proteins, representing up to $10 \%$ of the total protein in the cell. For example, $1 \mathrm{~g}$ of tissue contains approximately $2.5 \mathrm{mg}$ of HSPs. The lysis of $10^{5}$ to $10^{6}$ cells (approximately $1 \mathrm{mg}$ ) would result in the release of approximately $2 \mu \mathrm{g}$ HSP, translating to a local concentration of $1-2 \mathrm{mg} / \mathrm{mL}$ at the tissue level [47]. Second, several of the HSPs are markedly induced (up to $15 \%$ of the total 
Table 2. "Leaderless" Proteins Involved in the Host Immune Response

\begin{tabular}{|c|c|c|}
\hline PROTEIN & EXTRACELLULAR FUNCTION & INTRACELLULAR FUNCTION \\
\hline \hline IL-1 $\alpha$ & Pro-inflammatory cytokine & Activator of transcription \\
\hline IL-1 $\beta$ & Pro-inflammatory cytokine & - \\
\hline IL-18 & Pro-inflammatory cytokine & IL-1/IL-18 converting enzyme \\
\hline Caspase I (ICE) & $?$ & Chromatin component \\
\hline HMGB1 & Pro-inflammatory cytokine & - \\
\hline IL-16 & Pro-inflammatory cytokine & Transcription factor modulator \\
\hline MIF & Pro-inflammatory cytokine & \\
\hline
\end{tabular}

intracellular protein content) in response to a diverse range of cellular insults, including increased temperature, oxidative stress, glucose deprivation, chemical exposure, I/R injury, ultraviolet radiation, and infectious agents such as LPS. Third, HSPs are ancient, highly conserved molecules that have been identified in virtually every organism, both prokaryotic and eukaryotic, that have been examined to date. In comparison, LPS, an important "exogenous" danger signal, appeared relatively late on the evolutionary timescale and is much less ubiquitous, being unique to only gram-negative bacteria. It is tempting to speculate that the programmed response to the exogenous "danger signal", LPS, is modeled on the more primitive programmed response to the endogenous "danger signal" [47]. Fourth, HSPs are highly immunomodulatory and have the capacity to mediate the induction of peptide-specific immunity. For example, as molecular chaperones, HSPs bind to many peptides derived from the cells from which they are isolated. HSP-peptide complexes elicit potent $T$ cell responses against the chaperoned peptide as well as the cell type from which the chaperoned peptide is derived, including tumors and viruses, and vaccination with HSP-tumor peptide complexes as an immunotherapy for cancer is an active area of investigation [44-45, 47-50]. Similarly, HSP-pathogenderived peptide complexes have the capacity to elicit a pathogen-specific immune response [45]. Finally, HSPs themselves, especially members of the Hsp70 (HSPA) and Hsp60 (HSPD) families, have the capacity to activate the host innate immune response, resulting in dendritic cell activation and maturation, activation of complement, and release of proinflammatory cytokines [51-62].

\section{POTENTIAL MECHANISMS OF RELEASE OF THE HEAT SHOCK PROTEINS}

One argument that is frequently cited against the purported role for extracellular HSPs as endogenous danger signals has been the lack of any clearly defined mechanism to explain their release into the extracellular environment [63]. Collectively, the HSPs lack the classic N-terminus leader sequence necessary for the canonical protein secretory pathway [64]. Of interest, several additional proteins involved in the host immune response similarly lack the classic N-terminus leader sequence and are secreted through non-classical pathways (Table 2) [65]. What many investigators fail to recognize, however, is that there are diverse secretory pathways utilized by both prokaryotic and eukaryotic organisms, many of which have only recently been elucidated [7, 66-69]. While HSPs undoubtedly are released during necrotic cell death, most studies suggest that this is not the major mechanism of release [20, 64, 70-73]. For example, several studies have shown that release of HSPs generally occurs in the absence of significant cell death $[20,64,70-76]$. Perhaps the best evidence comes from an experiment in which serum Hsp72 (HSPA) concentrations were measured in Sprague-Dawley rats following exposure to a cat. Rats were physically separated from the cat using a clear Plexi-glass shield. In this experiment, cat exposure induced a significant increase in both corticosterone and extracellular Hsp72 (HSPA) production. This response was not observed in adrenalectomized rats [77]. Finally, there are several studies demonstrating increased serum Hsp72 (HSPA) levels in patients following exercise [78-79]. Collectively, these studies strongly suggest that HSP are released via a specific, though as yet undefined, secretory mechanism.

Hsp72 (HSPA) is perhaps the best and most widely studied extracellular heat shock protein and was first reported in cultured rat embryo cells following exposure to increased temperature in the late 1980's [80]. The mechanism of release appeared to be specific, in that Hsp72 (HSPA) release could not be reproduced by induction of cell lysis through exposure to non-ionic detergents. However, the mechanism did not appear to involve classic secretory pathways either, as it was not inhibited by either colchicine or monensin, both of which inhibit this pathway. Finally, Hsp72 (HSPA) synthesized in the presence of a lysine amino acid analogue (aminoethyl cysteine) was not released from these cells, suggesting that the altered protein structure prevented interaction with an as yet unidentified, but specific secretory mechanism [80]. Several groups, including ours [70, 80-86] have shown that viable cells release Hsp72 (HSPA) in a specific and inhibitable manner. Monensin and brefeldin A are inhibitors of the classic endoplasmic reticulum (ER)/Golgi protein transport and secretory pathways. We have shown that Hsp72 (HSPA) release from THP-1 cells is not inhibited by either monensin or brefeldin A [70]. In this particular study, release of extracellular Hsp72 (HSPA) was early and sustained up to 24 hours following heat shock and did not require new protein synthesis. Others have shown that Hsp72 (HSPA) release 
from peripheral blood monocytes (PBMC) is inhibited by brefeldin A, but not monensin [84, 86]. Hsp72 (HSPA) release has also inhibited by methylamine and methyl- $\beta$ cyclodextrin, both of which inhibit protein secretion via lysosomal pathways [86]. Recent studies suggest that Hsp72 (HSPA) is actively released via an exosome-dependent, nonclassical protein secretory pathway [74, 76, 87].

\section{THE IMMUNOMODULATORY EFFECTS OF EX- TRACELLULAR HEAT SHOCK PROTEINS}

\section{Heat Shock Protein 72 (HSPA)}

Extracellular Hsp72 (HSPA) is a highly immunomodulatory protein with effects on both the innate and adaptive immune responses [6-7, 17]. In this regard, extracellular Hsp72 (HSPA) appears to specifically interact with a wide myriad of cell surface receptors, including TLR2, TLR4, LOX-1, CD91, CD94 (C-type lectin), CD40 and chemokine receptor CCR5 [45-46, 61, 88-90]. These studies have used a variety of approaches to demonstrate physical interactions between Hsp72 and the purported receptor protein and are reviewed further in an excellent discussion by Binder and colleagues [91]. Hsp72 (HSPA), consistent with its role as a "chaperokine" appears to stimulate pro-inflammatory gene expression in macrophage and monocyte cell lines via both TLR-2 and TLR-4 [51, 5354]. In addition, we have shown that extracellular Hsp72 (HSPA) stimulates pro-inflammatory gene expression in cultured bronchial epithelial cells [92], hepatocytes [93], neutrophils [71], and cardiomyocytes (Wheeler, unpublished data). Moreover, intratracheal administration of extracellular Hsp72 (HSPA) induced pro-inflammatory gene expression in mice, primarily through TLR4 and NF- $\mathrm{KB}$ activation [92]. Our group has also demonstrated that extracellular Hsp72 (HSPA) induces the endotoxin tolerance phenotype in THP1 cells. Preconditioning with low-dose Hsp72 (HSPA) reprogrammed the subsequent response to LPS, such that LPS-mediated TNF- $\alpha$ gene expression was markedly abrogated [70, 94]. Subsequent experiments have demonstrated that these effects are not exclusive to TLR4 ligands, but that Hsp72 (HSPA) preconditioning also reprograms the response to TLR2 ligands, such as Pam3CysK, lipoteichoic acid, peptidoglycan, heat-killed Staphylococcus aureus (HKSA), and Hsp72 (HSPA) itself (Wheeler, unpublished data).

Some of the immunomodulatory effects of extracellular Hsp72 (HSPA) and other heat shock proteins have been ascribed to the presence of bacterial contaminants in the recombinant protein [95-100]. However, extensive and elegantly performed experimental controls strongly suggest that it is indeed the heat shock protein itself that is responsible for these effects. Typically, these controls include (i) measuring the LPS content of the recombinant protein via Limulus amebocyte lysate assay (LAL) and adding this concentration to control; (ii) directly inhibiting LPS activity with concomitant treatment with polymyxin B, lipid A, or lipid IVa treatment; (iii) heat denaturation or trypsin pretreatment of the recombinant protein to confim loss of immunomodulatory activity; and (iv) comparing immunomodulatory activity of the recombinant protein to irrelevant polypeptide sequences or similar sized proteins [101]. In addition, Hsp72 (HSPA) purified from liver cell lysates induced secretion of IL-1 $\beta$, TNF- $\alpha$, and IL-12 by murine macrophages [52]. Similarly, we have shown that endogenously released Hsp72 (HSPA) induces cellular reprogramming in THP-1 cells [70]. Neutralizing antibodies directed against extracellular Hsp72 (HSPA) have been shown to inhibit these pro-inflammatory effects [29]. Finally, an important consideration is whether extracellular Hsp72 (HSPA) chaperones small amounts of LPS and other PAMPs to their respective cell surface receptors, thereby augmenting stimulation of the innate immune response [101]. With this in mind, the effects of Hsp72 (HSPA) on the innate immune response in the absence of bacterial contaminants may be moot.

Extracellular Hsp72 (HSPA) has additional effects on the innate immune response. For example, extracellular Hsp72 (HSPA) both directly [102-103] and indirectly (by stimulating increased chemokine synthesis) [71, 92] induces neutrophil and dendritic cell chemotaxis. In addition, extracellular Hsp72 (HSPA) appears to play an important role in priming dendritic cells, macrophages, monocytes, and natural killer cells $[40,46,63,101]$. To this end, extracellular Hsp72 (HSPA) enhances synthesis of proinflammatory cytokines and upregulates cell surface expression of MHC class II and other important costimulatory molecules on dendritic cells [51, 53-56]. Extracellular Hsp72 (HSPA) also directly stimulates macrophage phagocytic activity [104-106]. Extracellular Hsp72 (HSPA) induces natural killer (NK) cell activity [107110]. NK cells play an important role in both the innate and adaptive immune responses. These unique cells exert cytotoxicity through both direct effects (via perforin production) and via mediation of antibody-dependent cytotoxicity.

Extracellular Hsp72 (HSPA) also exerts important effects on the adaptive immune response. For example, Hsp72 is able to chaperone a large variety of immunomodulatory peptides derived from tumors, virally-infected cells, etc and deliver them to antigen presenting cells. These chaperone/peptide complexes subsequently generate peptidespecific T-lymphocyte-mediated responses both in vitro and in vivo. Several groups are currently attempting to exploit this unique facet of heat shock protein biology for vaccine development and cancer immunotherapy [40, 46, 49, 111113].

A few studies have been able to demonstrate uptake of extracellular Hsp72 (HSPA). More importantly, uptake of extracellular Hsp72 (HSPA) appears to confer some degree of stress tolerance $[85,114-117]$. While the data are far from complete, these studies at least suggest a potential autocrine or paracrine role for extracellular Hsp72 (HSPA), further supporting the concept that heat shock proteins are endogenous danger signals or alarmins.

Extracellular Hsp72 (HSPA) has been found in the blood, cerebrospinal fluid, and bronchoalveolar lavage fluid of critically ill children and adults with a variety of inflammatory disease states. For example, increased extracellular Hsp72 levels following cardiopulmonary bypass have been detected in both adults [118-119] and children (Wheeler, unpublished data). Increased extracellular Hsp72 (HSPA) levels correlate with poor outcome in 
critically ill patients with liver disease [120], coronary artery disease [121-124], pre-eclampsia [125], sickle cell disease vaso-occlusive crisis [126], diabetic ketoacidosis [127], and septic shock [128]. Extracellular Hsp72 (HSPA) levels in the cerebrospinal fluid (CSF) of children with traumatic brain injury also appear to correlate with poor outcome [129]. Finally, extracellular Hsp72 (HSPA) has been found in the pulmonary edema fluid of adults with acute lung injury [130] and the urine of children following renal transplantation [131]. Given the signaling properties recently ascribed to Hsp72 (HSPA), these data suggest that the release of Hsp72 (HSPA) could potentiate an already active host immune response, thereby leading to poor outcome [132]. Alternatively, extracellular Hsp72 (HSPA) could serve an as yet undefined cytoprotective function at lower levels as a normal response to infection or stress, and once a certain critical threshold is attained, it could potentiate the dysregulated inflammatory response that subsequently results in multiple organ failure. Recent experimental data [133] and the finding that extracellular Hsp72 (HSPA) levels $>15 \mathrm{ng} / \mathrm{mL}$ correlated with improved outcome following multiple trauma in adults [134] support this concept. As such, it is tempting to speculate that lower levels of extracellular Hsp72 (HSPA) "cool down" the host inflammatory response, while higher levels further stimulate and/or augment the host inflammatory response. These important questions remain an active focus of investigation in many laboratories, including our own.

\section{Hsp27 (HSPB1)}

Hsp27 (HSPB1) is a member of the so-called small heat shock protein family (HSPB). Within quiescent cells, it assists in the degradation and removal of damaged proteins and also slows the rate of actin microfilament polymerization [135]. Like several members of the heat shock protein family, Hsp27 (HSPB1) is highly stress inducible. Following cell stress, Hsp27 (HSPB1) is phosporylated and loses the ability to slow the rate of actin polymerization, resulting in stabilization of the cellular cytoskeleton. Additionally, Hsp27 (HSPB1) has been shown to protect cells against apoptosis through the prevention of downstream caspase activation [136].

Hsp27 (HSPB1) is released from peripheral blood monocytes following treatment with TNF- $\alpha$ [137]. Extracellular Hsp27 (HSPB1) appears to possess antiinflammatory properties, with the target cell type determining the functionality. However, the receptor through which extracellular Hsp27 (HSPB1) inhibits inflammation is as yet poorly defined. Hsp27 (HSPB1) inhibits neutrophil apoptosis and potentially allows for exaggerated tissue destruction during sepsis, trauma, and acute lung injury [138]. In stark contrast to the exogenous danger signal, LPS, Hsp27 (HSPB1) inhibits neutrophil apoptosis without increasing pro-inflammatory cytokine production [138]. Hsp27 (HSPB1) induces expression of the anti-inflammatory cytokine, IL-10, in monocytes, primarily through the p38 protein kinase pathway, with only a mild increase in TNF- $\alpha$ levels [139-140]. Hsp27 (HSPB1) also inhibits monocyte differentiation into mature dendritic cells or macrophages[141].
These anti-inflammatory effects may be exploited by tumor cells, as the dampening of the host immune response may allow tumor progression and metastasis [142]. For example, increased serum levels of Hsp27 (HSPB1) have been associated with worse outcome in women with breast, ovarian, and uterine cancer [143]. In contrast, antibodies to Hsp27 (HSPB1) have been identified in the blood of women with breast cancer and other gynecologic cancers [144-145]. Those women with the highest levels of anti-Hsp27 serum antibodies seemed to have improved breast cancer survival [146]. Increased tumor expression of Hsp27 (HSPB1) is associated with shorter cancer free periods and advanced cancer staging, possibly due to the inhibition of tumor cell apoptosis [147]. Other studies have contradicted these findings, with no demonstrated association between serum Hsp27 (HSPB1) levels and cancer survival [147-148]. Hsp27 (HSPB1) also appears to be released from some brain tumor cells to dampen the immune response, inhibit apoptosis, and allow for tumor growth, progression, and metastasis [149]. The anti-inflammatory properties of Hsp27 (HSPB1) may be potentially exploited for the treatment of inflammatory disease processes. For example, Hsp27 (HSPB1) administration improves motor neuron survival for up to one week following nerve transection in neonatal mice [150].

In addition to playing a role in tumor growth and progression, extracellular Hsp27 (HSPB1) appears to play a role in the pathophysiology of cardiovascular disease. For example, Hsp27 (HSPB1) blocks lipid uptake by competitive inhibition of a low-density lipoprotein (LDL) scavenger receptor-A and decreases atherosclerotic plaque formation in vitro [140]. Clinically, extracellular Hsp27 (HSPB1) levels may be a reasonable biomarker for atherosclerosis disease progression [151-152]. Several studies have demonstrated an inverse association between Hsp27 (HSPB1) levels and atherosclerosis [151, 153-155]. However, a prospective study of 255 healthy women showed an inverse association with age but not serum Hsp27 (HSPB1) levels and future major cardiovascular events [154].

Higher levels of Hsp27 (HSPB1) have also been shown to protect mouse hearts from reperfusion injury and myocardial infarction[156]. In a small adult study, the expression of Hsp27 in transplanted hearts in acute rejection was elevated and thought to be a self-protective mechanism[157]. Further corroborating this theory, the vessels of transplanted hearts with higher phosphorylated levels of Hsp27 (HSPB1) upon biopsy demonstrated less cardiac allograft vasculopathy when compared to transplanted heart vessels with vasculopathy [158]. Similarly, and perhaps more relevant to the present discussion, there have been a few studies showing that elevated levels of Hsp27 (HSPB1) and/or decreased levels of autoantibodies to Hsp27 (HSPB1) correlate with improved outcome in patients with acute coronary syndrome [153, 159-160].

\section{Hsp90 (HSPC)}

Hsp90 (HSPC) is one of the most abundant proteins inside the cell. Hsp90 (HSPC) plays an important role in maintaining normal homeostasis and acts as a scaffolding protein for several key enzyme and signal transduction systems [161-163]. So far, however, there have been 
comparatively few reports describing Hsp90 (HSPC) in the extracellular environment. We have shown that increased plasma Hsp90 (HSPC) levels correlate with worse outcome in critically ill children with septic shock (Wheeler, unpublished data). In addition, extracellular Hsp90 (HSPC) induces IL-8 gene expression in cultured vascular smooth muscle cells in a TLR4- and NF-B-dependent manner [164]. Finally, a human recombinant antibody directed against yeast-derived Hsp90 (HSPC) has been used to treat critically ill patients with invasive candidiasis. In this study, recombinant antibody to Hsp90 plus lipid-associated amphotericin B produced significant clinical and cultureconfirmed improvement in outcome for patients with invasive candidiasis [165-168]. Given these data, it is very likely that future studies will demonstrate functional roles for extracellular Hsp90 (HSPC).

\section{Hsp60 (HSPD)}

Hsp60 (HSPD) is a key mitochondrial chaperone that forms a complex with the chaperonin (Cpn)/Hsp10 (HSPE) [169-170]. Extracellular human Hsp60 (HSPD) appears to be involved in many autoimmune and inflammatory processes within the body. Some of these processes are thought to be triggered by a number of infectious agents through molecular mimicry, in which the initial host immune response to microbial-derived Hsp60 (HSPD) leads to a subsequent cross reaction to the host-derived Hsp60 (HSPD). For example, both Chlamydia pneumoniae Hsp60 (HSPD) and the host human Hsp60 (HSPD) have been detected in atheromas [171]. Both of these molecules were shown to have the ability to activate host macrophages and endothelial cells contributing to the progression of atherosclerosis [171]. For the purposes of this review however, only research involving isolated human Hsp60 will be discussed.

Circulating antibodies to human Hsp60 (HSPD) appear to play a role in the pathophysiology of a number of vasculopathies and related illnesses. For example, in an animal model of atherosclerosis, auto-antibodies to Hsp60 were shown to be involved in disease progression [172]. Increased circulating levels of anti-Hsp60 (HSPD) antibodies have been found in patients with carotid artery atherosclerosis [173]. Elevated Hsp60 (HSPD) antibodies were also found in patients with other vasculopathies, such as borderline hypertension [174]. Increased circulating antiHsp60 (HSPD) antibody titers have also been found in patients with coronary artery disease [175] and correlate with the presence and severity of disease after adjusting for traditional risk factors [176]. Interestingly, the antibody titers in coronary artery disease patients decreased after an acute myocardial infarction [175]. The authors speculated that a soluble form of Hsp60 (HSPD) must be released from the ischemic myocardial tissue to complex with the anti-Hsp60 (HSPD) antibodies [175]. This hypothesis was confirmed by several independent groups showing increased levels of Hsp60 (HSPD) following acute myocardial infarction [177178]. Similarly, increased circulating levels of both Hsp60 (HSPD) and anti-Hsp60 antibodies have been associated with an increased risk of developing coronary artery disease [178] and appear to correlate with increased severity of disease, even controlling for all other risk factors [179]. In a follow-up surveillance study enrolling healthy civil service workers, increased plasma Hsp60 (HSPD) levels correlated with increased plasma TNF- $\alpha$, psychological distress (primarily in women), low socioeconomic status, and social isolation [180], resulting in an increased propensity for coronary artery disease.

$\mathrm{Xu}$ and colleagues discovered an association between elevated circulating levels of Hsp60 (HSPD) and the progression and severity of carotid artery atherosclerosis [181]. This association was further investigated prospectively. Patients with a sustained elevation of serum Hsp60 (HSPD) were found to be at risk for the development of early atherosclerosis [182]. High levels were also found in patients with borderline hypertension which was again associated with the development of early cardiovascular disease [183]. However, when Hsp60 (HSPD) was measured in patients with chronic hypertension and chronic vascular disease, these levels were found to be similar to healthy controls [121, 184], potentially suggesting increased binding to anti-Hsp60 (HSPD) antibodies.

Extracellular Hsp60 (HSPD) plays a role in the pathophysiology of many autoimmune diseases [185]. For example, elevated $\operatorname{IgG}$ antibodies to Hsp60 (HSPD) are found in the sera of patients with rheumatic autoimmune diseases [186]. Host-derived Hsp60 (HSPD) appears to play a role in the regulation of autoimmune arthritis in rats [187188]. An antigen-specific T-cell response to Hsp60 (HSPD) was associated with improved outcome in patients with juvenile idiopathic arthritis (JIA) [189-190], possibly through increased IL-10 production by regulatory T-cells [191]. Armed with this data, vaccines against Hsp60 (HSPD) have shown promising results in models of arthritis and cyclophosphamide-accelerated diabetes [192-194].

It is becoming clearer that extracellular Hsp60 (HSPD) plays a role in inflammation and the body's immune response. To this end, we have shown that increased circulating Hsp60 (HSPD) levels correlates with poor outcome in critically ill children with septic shock [195]. Similar to extracellular Hsp72 (HSPA), Hsp60 (HSPD) appears to act primarily via the TLR4 pathway [196-197], though activation of the TLR2 pathway has also been observed [196]. Hsp60 (HSPD) activates human macrophages and dendritic cells to produce Th1 inflammatory cytokines such as TNF $\alpha$ and interferon (IFN)- $\gamma$ [198-199]. However, determining the specific cytokine profile may be dose dependent as both Th1 and Th2 cytokine profiles resulted when dendritic cells were treated with lower concentrations of Hsp60 (HSPD) [199]. Similar to LPS and extracellular Hsp72 (HSPA), Hsp60 (HSPD) may also be able to promote inflammation initially and then induce a state of tolerance [200-201], akin to the endotoxin tolerance phenotype. Again, the potential effects of contamination of the recombinant Hsp60 (HSPD) protein with bacterial products must be considered and assessed with the use of adequate controls (see discussion above).

Hsp60 (HSPD) also appears to activate the adaptive immune response. For example, Hsp60 (HSPD) can inhibit pro-inflammatory cytokine production and shift to an antiinflammatory $\mathrm{Th} 2$ profile in T lymphocytes [202]. However, 
other studies have shown that Hsp60 (HSPD) increases IFN$\gamma$ production in T lymphocytes [203]. Similarly, extracellular Hsp60 (HSPD) has been shown to activate B-cells in a mixed Th1 and Th2 manner with B-cells producing both IFN- $\gamma$ and IL-10 [204].

\section{Chaperonin (Cpn)/Hsp10 (HSPE)}

As discussed briefly above, Cpn/Hsp10 (HSPE) was the first heat shock protein to be isolated outside the cell. In this case, Cpn/Hsp10 (HSPE) was isolated from the serum of pregnant females as early pregnancy factor (EPF) [19, 205]. EPF was originally believed to be essential for the initiation and maintenance of the developing embryo during early pregnancy and was later found to be homologous to rat Cpn/Hsp10 (HSPE). EPF appears to have growth factor qualities [206], as well as anti-inflammatory properties which are necessary for protecting the embryo from the mother's own immune system [207-208]. Cpn/Hsp10 (HSPE) is released into circulation by dividing primitive cancer cells [206]. Cpn/Hsp10 (HSPE) forms a complex with the mitochondrial co-chaperone, Hsp60 (HSPD) and assists with the proper folding of mitochondrial proteins, as well as the reactivation of denatured proteins[170].

Relevant to the present discussion, Cpn/Hsp10 (HSPE) appears to modulate the innate immune system through interactions with monocytes, lymphocytes, and natural killer cells [208]. Disease specific animal models have produced compelling data describing the immunosuppressive activities of $\mathrm{Cpn} / \mathrm{Hsp} 10$ (HSPE). For example, it was shown to decrease the expression of leukocyte trafficking adhesion molecules and the immune response in an animal model of multiple sclerosis and delayed-type hypersensitivity [209]. The inflammatory response was also suppressed in animal models of allograft transplantation, resulting in increased graft survival [210-211]. The in vitro administration of recombinant Cpn/Hsp10 (HSPE) appeared to inhibit LPSinduced NF- $\mathrm{KB}$ activation, thereby decreasing inflammatory cytokine and chemokine production, as well [211].

\section{EXTRACELLULAR HEAT SHOCK PROTEINS AND SEPSIS}

Our understanding of the relative contribution of intracellular versus extracellular HSPs in the pathophysiology of the sepsis syndrome is far from complete. For example, numerous in vitro and in vivo studies suggest that augmenting the intracellular expression of HSPs is beneficial to the host $[5-7,17,212-213]$. Indeed, the discovery of innovative methods of augmenting intracellular HSP expression in the clinical setting remains an active area of focus for several laboratories, including our own. On the other hand, there is compelling evidence that extracellular HSPs augment the host innate and adaptive immune response (discussed above). The immunomodulatory effects (i.e. either stimulatory or inhibitory) of extracellular HSPs are largely dependent upon contextual factors. Rather than viewing intracellular and extracellular HSP expression as two independent and mutually exclusive processes, we hypothesize that moderate levels of stress, such that would occur in critically ill patients with sepsis, increase both intracellular HSP expression and extracellular release of HSP, likely through some as yet undefined active, secretory mechanism. These two events result in enhanced protection for both the host cell, as well as cells in the immediate surroundings through either active uptake (and enhanced protection through increased intracellular HSP expression) or activation of stress response programs. Conversely, greater levels of stress further augment intracellular HSP expression and cause necrotic cell death, resulting in the release of large quantities of HSPs and causing an overzealous activation of the host inflammatory response through their immunostimulatory effects.

\section{CONCLUSION}

The stress response is characterized by a rapid increase in both the intracellular expression and subsequent release of a unique group of proteins, known as heat shock proteins. While intracellular HSPs predominantly down-regulate the host inflammatory response, extracellular HSPs may increase or decrease the host inflammatory response. The extracellular HSPs are now included in a growing list of socalled danger-associated molecular patterns (DAMPs), or alarmins. Further studies are necessary to better characterize the effects of these special proteins on the host inflammatory response during sepsis.

\section{ACKNOWLEDGEMENT}

Supported by the National Institutes of Health, K08GM077432 (DSW), R03HD058246 (DSW).

\section{REFERENCES}

[1] De Maio A. The heat-shock response. New Horiz 1995;3:198-207.

[2] De Maio A. Heat shock proteins: Facts, thoughts, and dreams. Shock 1999;11:1-12.

[3] Ritossa F. A new puffing pattern induced by temperature shock and DNP in Drosophila. Experientia 1962;18:571-3.

[4] Ritossa F. Discovery of the heat shock response. Cell Stress Chaperones 1996;1:97-8.

[5] Wong HR, Wispe JR. The stress response and the lung. Am J Physiol 1997;273:L1-L9.

[6] Wheeler DS, Wong HR. Heat shock response and acute lung injury. Free Radic Biol Med 2007;42:1-14.

[7] Wheeler DS, Zingarelli B, Wong HR. The role of extracellular heat shock proteins in cellular inflammation and injury. Vincent J-L, editor. Berlin, Germany: Springer-Verlag; 2006.

[8] Kampinga HH, Hageman J, Vos MJ, et al. Guidelines for the nomenclature of the human heat shock proteins. Cell Stress Chaperones 2009;14:105-11.

[9] Wong HR, Odoms K, Sakthivel B. Divergence of canonical danger signals: The genome-level expression patterns of human mononuclear cells subjected to heat shock or lipopolysaccharide. BMC Immunol 2008;9:24.

[10] Sonna LA, Hawkins L, Lissauer ME, et al. Core temperature correlates with expression of selected stress and immunomodulatory genes in febrile patients with sepsis and noninfectious SIRS. Cell Stress Chaperones 2010;15:55-66.

[11] Bond U, Schlesinger MJ. Ubiquitin is a heat shock protein in chicken embryo fibroblasts. Mol Cell Biol 1985;5:949-56.

[12] Muller-Taubenberger A, Hagmann J, Noegel A, Gerisch G. Ubiquitin gene expression in Dictyostelium is induced by heat and cold shock, cadmium, and inhibitors of protein synthesis. J Cell Sci 1988;90:51-8.

[13] Ryter SW, Otterbein LE, Morse D, Choi AM. Heme oxygenase/carbon monoxide signaling pathways: regulation and functional significance. Mol Cell Biochem 2002 ;234-235:249-63.

[14] Dunsmore KE, Denenberg AG, Page K, Wong HR. Mechanism and function of heat shock-dependent IkappaBalpha expression. Inflamm Res 2006;55:254-9.

[15] Harris MB, Blackstone MA, Ju H, Venema VJ, Venema RC. Heatinduced increases in endothelial NO synthase expression and 
activity and endothelial NO release. Am J Physiol Heart Circ Physiol 2003;285:H333-H40.

[16] Wong HR, Dunsmore K, Page K, Shanley TP. Heat shockmediated regulation of MKP-1. Am J Physiol Cell Physiol 2005;289:C1152-C8.

[17] Wheeler DS, Wong HR. The heat shock response and transplantation immunology. Wilkes DS, Burlingham WD, editors. New York: Kluwer Academic/Plenum Publishers; 2004.

[18] Morton H, Rolfe B, Clunie GJ. An early pregnancy factor detected in human serum by the rosette inhibition test. Lancet 1977;1:394-7.

[19] Cavanagh AC, Morton H. The purification of early-pregnancy factor to homogeneity from human platelets and identification as chaperonin 10. Eur J Biochem 1994; 222:551-60.

[20] Hightower LE, Guidon PTJ. Selective release from cultured mammalian cells of heat-shock (stress) proteins that resemble gliaaxon transfer proteins. J Cell Physiol 1989;138:257-66.

[21] Wallin RP, Lundqvist A, More SH, von Bonin A, Kiessling R, Ljunggren HG. Heat-shock proteins as activators of the innate immune system. Trends Immunol $2002 ; 23: 130-5$.

[22] Matzinger P. An innate sense of danger. Semin Immunol 1998;10:399-415.

[23] Jerome KR, Corey L. The danger within. N Engl J Med 2004;350:411-2.

[24] Skoberne M, Beignon AS, Bhardwaj N. Danger signals: A time and space continuum. Trends Mol Med 2004;10:251-7.

[25] Mollen KP, Anand RJ, Tsung A, Prince JM, Levy RM, Billiar TR. Emerging paradigm: Toll-like receptor 4-sentinel for the detection of tissue damage. Shock 2006;26:430-7.

[26] Bianchi ME. DAMPs, PAMPs, and alarmins: All we need to know about danger. J Leukocyte Biol 2007;81:1-5.

[27] Oppenheim JJ, Yang D. Alarmins: Chemotactic activators of immune responses. Curr Opin Immunol 2005;17:359-65.

[28] Yang D, Chen Q, Yang H, Tracey KJ, Bustin M, Oppenheim JJ. High mobility group box-1 protein induces the migration and activation of human dendritic cells and acts as an alarmin. J Leukocyte Biol 2007;81:59-66.

[29] El Mezayen R, El Gazzar M, Seeds MC, McCall CE, Dreskin SC, Nicolls MR. Endogenous signals released from necrotic cells augment inflammatory responses to bacterial endotoxin. Immunol Lett 2007;111:36-44.

[30] Palumbo R, Galvez BG, Pusterla T, et al. Cells migrating to sites of tissue damage in response to the danger signal HMGB1 require NF-kappaB activation. J Cell Biol 2007;179:33-40.

[31] Klune JR, Dhupar R, Cardinal J, Billiar TR, Tsung A. HMGB1: Endogenous danger signaling. Mol Med 2008;14:476-84.

[32] Klune JR, Billiar TR, Tsung A. HMGB1 preconditioning: Therapeutic application for a danger signal? J Leukocyte Biol 2008;83:558-63.

[33] Williams JH, Ireland HE. Sensing danger - Hsp72 and HMGB1 as candidate signals. J Leukoc Biol 2008;83:489-92.

[34] Shi Y, Evans JE, Rock KL. Molecular identification of a danger signal that alers the immune system to dying cells. Nature 2003;425:516-21.

[35] Martinon F, Petrilli V, Mayor A, Tardivel A, Tschopp J. Goutassociated uric acid crystals activate the NALP3 inflammasome. Nature 2006;440:237-41.

[36] Zare F, Magnusson M, Bergstrom T, et al. Uric acid, a nucleic acid degradation product, down-regulates dsRNA-triggered arthritis. J Leukocyte Biol 2006;79:482-8.

[37] Liu $K$, Inoue $H$, Nakayama $H$, Kanno $R$, Kanno $M$. The endogenous danger signal uric acid augments contact hypersensitivity responses in mice. Pathobiology 2007;74:177-85.

[38] Behrens MD, Wagner WM, Krco CJ, et al. The endogenous danger signal, crystalline uric acid, signals for enhanced antibody immunity. Blood 2008;111:1472-9.

[39] Gasse P, Riteau N, Charron S, et al. Uric acid is a danger signal activating NALP3 inflammasome in lung injury inflammation and fibrosis. Am J Respir Crit Care Med 2009;179:903-13.

[40] Calderwood SK, Mambula SS, Gray PJJ. Extracellular heat shock proteins in cell signaling and immunity. Ann N Y Acad Sci 2007;1113:28-39.

[41] Calderwood SK, Mambula SS, Gray PJJ, Theriault JR. Extracellular heat shock proteins in cell signaling. FEBS Lett 2007;581:3689-94.

[42] Zedler S, Faist E. The impact of endogenous triggers on traumaassociated inflammation. Curr Opin Crit Care 2006;12:595-601.
[43] Kaczorowski DJ, Mollen KP, Edmonds R, Billiar TR. Early events in the recognition of danger signals after tissue injury. J Leukocyte Biol 2008;83:546-52.

[44] Pockley AG. Heat shock proteins in health and disease: Therapeutic targets or therapeutic agents? Expert Rev Mol Med 2001;2001:1-21.

[45] Pockley AG. Heat shock proteins as regulators of the immune response. Lancet. 2003;362:469-76.

[46] Pockley AG, Muthana M, Calderwood SK. The dual immunoregulatory roles of stress proteins. Trends Biochem Sci 2008;33:71-9.

[47] Anderson KM, Srivastava PK. Heat, heat shock, heat shock proteins and death: A central link in innate and adaptive immune responses. Immunol Lett 2000;74:35-9.

[48] Robert J. Evolution of heat shock protein and immunity. Dev Comp Immunol 2003;27:449-64.

[49] Tamura Y, Peng P, Liu K, Daou M, Srivastava PK. Immunotherapy of tumors with autologous tumor-derived heat shock protein preparations. Science 1997;278:117-20.

[50] Srivastava PK, Menoret A, Basu S, Binder RJ, McQuade KL. Heat shock proteins come of age: Primitive functions acquire new roles in an adaptive world. Immunity 1998;8:657-65.

[51] Asea A, Kraeft SK, Kurt-Jones EA, Stevenson MA, Chen LB, Finberg RW, et al. HSP70 stimulates cytokine production through a CD14-dependant pathway, demonstrating its dual role as a chaperone and cytokine. Nat Med $2000 ; 6: 435-42$.

[52] Basu S, Binder RJ, Suto R, Anderson KM, Srivastava PK. Necrotic but not apoptotic cell death releases heat shock proteins, which deliver a partial maturation signal to dendritic cells and activate the NF-kappaB pathway. Int Immunol 2000;12:1539-46.

[53] Asea A, Kabingu E, Stevenson MA, Calderwood SK. HSP70 peptide-bearing and peptide-negative preparations act as chaperokines. Cell Stress Chaperones 2000;5:425-31.

[54] Asea A, Rehli M, Kabingu E, et al. Novel signal transduction pathway utilized by extracellular HSP70: role of toll-like receptor (TLR) 2 and TLR4. J Biol Chem 2002 ;277:15028-34.

[55] Vabulas RM, Ahmad-Nejad P, Ghose S, Kirschning CJ, Issels RD, Wagner H. HSP70 as endogenous stimulus of the Toll/Interleukin1 receptor signal pathway. J Biol Chem 2002;277:15107-12.

[56] Bethke K, Staib F, Distler M, et al. Different efficiency of heat shock proteins (HSP) to activate human monocytes and dendritic cells: superiority of HSP60. J Immunol 2002;169:6141-8.

[57] Panjwani NN, Popova L, Srivastava PK. Heat shock proteins gp96 and hsp 70 activate the release of nitric oxide by APCs. J Immunol 2002;168:2997-3003.

[58] Prohaszka Z, Singh M, Nagy K, et al. Heat shock protein 70 is a potent activator of the human complement system. Cell Stress Chaperones. $2002 ; 7: 17-22$.

[59] Feng H, Zeng Y, Graner MW, Katsanis E. Stressed apoptotic tumor cells stimulate dendritic cells and induce specific cytotoxic T cells. Blood 2002;100:4108-15.

[60] Radsak MP, Hilf N, Singh-Jasuja H, et al. The heat shock protein Gp96 binds to human neutrophils and monocytes and stimulates effector functions. Blood 2003;101:2810-5.

[61] Campisi J, Leem TH, Fleshner M. Stress-induced extracellular Hsp72 is a functionall significant danger signal to the immune system. Cell Stress Chaperones 2003;8:272-86.

[62] Tsan M-F, Gao B. Endogenous ligans of Toll-like receptors. J Leukoc Biol 2004;76:514-9.

[63] Henderson B, Henderson S. Unfolding the relationship between secreted molecular chaperones and macrophage activation states. Cell Stress Chaperones 2009;14:329-41.

[64] Mambula SS, Stevenson MA, Ogawa K, Calderwood SK. Mechanisms for Hsp70 secretion: Crossing membranes without a leader. Methods 2007;43:168-75.

[65] Chimini G, Rubartelli A. Novel pathways of protein secretion. In: Henderson B, Pockley AG, editors. Molecular Chaperones and Cell Signaling. New York: Cambridge University Press; 2005. p. 45-60.

[66] Prudovsky I, Mandinova A, Soldi R, et al. The non-classical export routes: FGF1 and IL-1alpha point the way. J Cell Sci 2003;116:4871-81

[67] Prudovsky I, Tarantini F, Landriscina M, et al. Secretion without Golgi. J Cell Biochem 2008;103:1327-43.

[68] Nickel W, Seedorf M. Unconventional mechanisms of protein transport to the cell surface of eukaryotic cells. Annu Rev Cell Dev Biol 2008;24:287-308. 
[69] Cascales E. The type VI secretion toolkit. EMBO Rep 2008;9:73541.

[70] Abboud PA, Lahni PM, Page K, et al. The role of endogenously produced extracellular hsp72 in mononuclear cell reprogramming. Shock 2008;30:285-92.

[71] Wheeler DS, Chase MA, Senft AP, Poynter SE, Wong HR, Page K. Extracellular Hsp72, an endogenous DAMP, is released by virally infected airway epithelial cells and activates neutrophils via Tolllike receptor (TLR)-4. Respir Res 2009;10:31.

[72] Mambula SS, Calderwood SK. Heat shock protein 70 is secreted from tumor cells by a nonclassical pathway involving lysosomal endosomes. J Immunol 2006;177:7849-57.

[73] Mambula SS, Calderwood SK. Heat induced release of Hsp70 from prostate carcinoma cells involves both active secretion and passive release from necrotic cells. Int J Hyperthermia 2006;22:575-85.

[74] Lancaster GI, Febbraio MA. Exosome-dependent trafficking of HSP70: A novel secretory pathway for cellular stress proteins. J Biol Chem 2005;280:23349-55.

[75] Hunter-Lavin C, Davies EL, Bacelar MM, Marshall MJ, Andrew SM, Williams JH. Hsp70 release from peripheral blood mononuclear cells. Biochem Biophys Res Commun 2004;324:5117.

[76] Vega VL, Rodriguez-Silva M, Frey T, et al. Hsp70 translocates into the plasma membrane after stress and is released into the extracellular environment in a membrane-associated form that activates macrophages. J Immunol 2008;180:4299-307.

[77] Fleshner M, Campisi J, Amiri L, Diamond DM. Cat exposure induces both intra- and extracellular Hsp72: The role of adrenal hormones. Psychoneuroendocrinology 2004;29:1142-52.

[78] Lancaster GI, Febbraio MA. Mechanisms of stress-induced cellular HSP72 release: Implications for exercise-induced increases in extracellular HSP72. Exerc Immunol Rev 2005;11:46-52.

[79] Whitham M, Fortes MB. Heat shock protein 72: Release and biological significance during exercise. Front Biosci 2008;13:132839.

[80] Hightower LE, Guidon PT, Jr. Selective release from cultured mammalian cells of heat-shock (stress) proteins that resemble gliaaxon transfer proteins. J Cell Physiol 1989;138:257-66.

[81] Barreto A, Gonzalez JM, Kabingu E, Asea A, Fiorentino S. Stressinduced release of HSC70 from human tumors. Cell Immunol 2003;222:97-104.

[82] Febbraio MA, Steensberg A. Reduced glycogen availability is associated with an elevation in HSP72 in contracting skeletal muscle. J Physiol 2002;538:911-7.

[83] Lancaster GI, Moller K, Nielsen B, Secher NH, Febbraio MA, Nybo L. Exercise induces the release of heat shock protein 72 from the brain in vivo. Cell Stress Chaperones 2004;9:276-80.

[84] Ernani FP, Teale JM. Release of stress proteins from Mesocestoides corti is a brefeldin A-inhibitable process: evidence for active export of stress proteins. Infect Immun 1993 ;61:2596601 .

[85] Guzhova I, Kislyakova K, Moskaliova O, et al. In vitro studies show that Hsp70 can be released by glia and that exogenous Hsp70 can enhance neuronal stress tolerance. Brain Res 2001 28;914:6673.

[86] Hunter-Lavin C, Davies EL, Bacelar MMFVG, Marshall MJ, Andrew SM, Williams JHH. Hsp70 release from peripheral blood mononuclear cells. Biochem Biophys Res Commun 2004;324:5117.

[87] Bausero M, Gastpar R, Multhoff G, Asea A. Alternative mechanism by which IFN-gamma enhances tumor recognition: Active release of heat shock protein 72. J Immunol 2005;175:290012.

[88] Milani V, Noessner E, Ghose S, et al. Heat shock protein 70: Role in antigen presentation and immune stimulation. Int $\mathrm{J}$ Hyperthermia 2002;18:563-75.

[89] Todryk SM, Gough MJ, Pockley AG. Facets of heat shock protein 70 show immunotherapeutic potential. Immunology 2003;110:1-9.

[90] Johnson JD, Fleshner M. Releasing signals, secretory pathways, and immune function of endogenous extracellular heat shock protein 72. J Leukoc Biol 2006;79:425-34.

[91] Binder RJ, Vatner R, Srivastava P. The heat-shock protein receptors: Some answers and more questions. Tissue Antigens 2004;64:442-51

[92] Chase MA, Wheeler DS, Lierl KM, Hughes VS, Wong HR, Page $\mathrm{K} . \mathrm{Hsp} 72$ induces inflammation and regulates cytokine production in airway epithelium through a TLR4 and NF-kappaB-dependent mechanisms. J Immunol 2007;179:6318-24.

[93] Galloway E, Shin T, Huber N, et al. Activation of hepatocytes by extracellular heat shock protein 72. Am J Physiol Cell Physiol 2008;295:C514-C20.

[94] Aneja R, Odoms K, Dunsmore K, Shanley TP, Wong HR. Extracellular heat shock protein-70 induces endotoxin tolerance in THP-1 cells. J Immunol 2006;177:7184-92.

[95] Gao B, Tsan M-F. Endotoxin contamination in recombinant human heat shock protein (Hsp70) preparation is responsible for the induction of tumor necrosis factor alpha release by murine macrophages. J Biol Chem 2003;278:174-9.

[96] Gao B, Tsan M-F. Recombinant human heat shock protein 60 does not induce the release of tumor necrosis factor alpha from murine macrophages. J Biol Chem 2003;278:22523-9.

[97] Gao B, Tsan M-F. Induction of cytokines by heat shock proteins and endotoxin in murine macrophages. Biochem Biophys Res Commun 2004;317:1149-54.

[98] Tsan M-F, Gao B. Endogenous ligands of Toll-like receptors. J Leukoc Biol 2004;76:514-9.

[99] Tsan M-F, Gao B. Heat shock proteins and immune system. J Leukoc Biol 2009;85:905-10.

[100] Bausinger H, Lipsker D, Ziylan U, et al. Endotoxin-free heat-shock protein 70 fails to induce APC activation. Eur J Immunol 2002;32:3708-13.

[101] de Jong PR, Schadenberg AW, Jansen NJ, Prakken BJ. Hsp70 and cardiac surgery: Molecular chaperone and inflammatory regulator with compartmentalized effects. Cell Stress Chaperones 2009; $14: 117-31$.

[102] Ortega E, Hinchado MD, Martin-Cordero L, Asea A. The effect of stress-inducible extracellular Hsp72 on human neutrophil chemotaxis: A role during acute intense exercise. Stress 2009; 12:240-9.

[103] Chen T, Guo J, Han C, Yang M, Cao X. Heat shock protein 70, released from heat-stressed tumor cells, initiates antitumor immunity by inducing tumor cell chemokine production and activating dendritic cells via TLR4 pathway. J Immunol 2009;182:1449-559.

[104] Kovalchin JT, Wang R, Wagh MS, Azoulay J, Sanders M, Chandawarkar RY. In vivo delivery of heat shock protein 70 accelerates wound healing by up-regulating macrophage-mediated phagocytosis. Wound Repair Regen 2006;14:129-37.

[105] Wang R, Kovalchin JT, Muhlenkamp P, Chandawarkar RY. Exogenous heat shock protein 70 binds macrophage lipid raft microdomain and stimulates phagocytosis, processing, and MHC-II presentation of antigens. Blood 2006;107:1636-42.

[106] Wang R, Town T, Gokarn V, Flavell RA, Chandawarkar RY. HSP70 enhances macrophage phagocytosis by interaction with lipid raft-associated TLR-7 and upregulating p38 MAPK and PI3K pathways. J Surg Res 2006;136:58-69.

[107] Multhoff G, Botzler C, Jennen L, Schmidt J, Ellwart J, Issels R. Heat shock protein 72 on tumor cells: A recognition structure for natural killer cells. J Immunol 1997;158:4341-50.

[108] Multhoff G, Pfister K, Gehrmann M, et al. A 14-mer Hsp70 peptide stimulates natural killer (NK) cell activity. Cell Stress Chaperones 2001;6:337-44.

[109] Qiao Y, Liu B, Li Z. Activation of NK cells by extracellular heat shock protein 70 through induction of NKG2D ligands on dendritic cells. Cancer Immun 2008;8:12.

[110] Horn P, Kalz A, Lim CL, et al. Exercise-recruited NK cells display exercise-associated eHSP-70. Exerc Immunol Rev 2007;13:100-11.

[111] Javid B, MacAry PA, Lehner PJ. Structure and function: Heat shock proteins and adaptive immunity. J Immunol 2007;179:203540.

[112] Spisek R, Dhodapkar MV. Towards a better way to die with chemotherapy: Role of heat shock protein exposure on dying tumor cells. Cell Cycle 2007;6:1962-5.

[113] Wang XY, Kaneko Y, Repasky E, Subjeck JR. Heat shock proteins and cancer immunotherapy. Immunol Invest 2000;29:131-7.

[114] Tytell M, Greenberg SG, Lasek RJ. Heat shock-like protein is transferred from glia to axon. Brain Res 1986;363:161-4.

[115] Johnson AD, Berberian PA, Bond MG. Effect of heat shock proteins on survival of isolated aortic cells from normal and atherosclerotic cynomolgus macaques. Atherosclerosis 1990;84:111-9. 
[116] Robinson MB, Tidwell JL, Gould T, et al. Extracellular heat shock protein 70: A critical component for motoneuron survival. J Neurosci 2005;25:9735-45.

[117] Tidwell JL, Houenou LJ, Tytell M. Administration of Hsp70 in vivo inhibits motor and sensory neuron degeneration. Cell Stress Chaperones 2004;9:88-98.

[118] Sharma M, Ganguly NK, Chaturvedi G, Thingnam SKS, Majumdar $\mathrm{S}$, Suri RK. A possible role of HSP70 in mediating cardioprotection in patients undergoing CABG. Mol Cell Biochem 2003;247:31-6.

[119] Dybdahl B, Wahba A, Haaverstad R, et al. On-pump versus offpump coronary artery bypass grafting: more heat-shock protein 70 is released after on-pump surgery. Eur J Cardiothorac Surg 2004 ;25:985-92.

[120] Kimura F, Itoh H, Ambiru S, Shimizu H, Togawa A, Yoshidome $\mathrm{H}$, et al. Circulating heat-shock protein 70 is associated with postoperative infection and organ dysfunction after liver resection. Am J Surg 2004 ;187:777-84.

[121] Pockley AG, De Faire U, Kiessling R, Lemne C, Thulin T, Frostegard J. Circulating heat shock protein and heat shock protein antibody levels in established hypertension. J Hypertens. 2002;20:1815-20.

[122] Pockley AG, Georgiades A, Thulin T, de Faire U, Frostegard J. Serum heat shock protein 70 levels predict the development of atherosclerosis in subjects with established hypertension. Hypertension. 2003 ;42:235-8.

[123] Dybdahl B, Slordahl SA, Waage A, Kierulf P, Espevik T, Sundan A. Myocardial ishaemia and the inflammatory response: Release of heat shock protein 70 after myocardial infarction. Heart 2005;91:299-304.

[124] Genth-Zotz S, Bolger AP, Kalra PR, et al. Heat shock protein 70 in patients with chronic heart failure: Relation to disease severity and survival. Int J Cardiol 2003;96:397-401.

[125] Fukushima A, Kawahara H, Isurugi C, et al. Changes in serum levels of heat shock protein 70 in preterm delivery and preeclampsia. J Obstet Gynaecol Res 2005;31:72-7.

[126] Adewoye AH, Klings ES, Farber HW, et al. Sickle cell vasoocclusive crisis induces the release of circulating serum heat shock protein-70. Am J Hematol 2005;78:240-2.

[127] Oglesbee MJ, Herdman AV, Passmore GG, Hoffman WH. Diabetic ketoacidosis increases extracellular levels of the major inducible 70-kDa heat shock protein. Clin Biochem 2005;38:900-4.

[128] Wheeler DS, Fisher LE, Catravas JD, Jacobs BR, Carcillo JA, Wong HR. Extracellular hsp70 levels in children with septic shock. Pediatr Crit Care Med 2005;6:308-11.

[129] Lai Y, Kochanek PM, Adelson PD, Janesko K, Ruppel RA, Clark RS. Induction of the stress response after inflicted and non-inflicted traumatic brain injury in infants and children. J Neurotrauma 2004 ;21:229-37.

[130] Ganter MT, Ware LB, Howard M, et al. Extracellular heat shock protein 72 is a marker of the stress protein response in acute lung injury. Am J Physiol Lung Cell Mol Physiol. 2006 ;291:L354-61.

[131] Mueller T, Bidmon B, Pichler P, et al. Urinary heat shock protein72 excretion in clinical and experimental renal ischemia. Pediatr Nephrol 2003;18:97-9.

[132] Quintana FJ, Cohen IR. Heat shock proteins as endogenous adjuvants in sterile and septic inflammation. J Immunol 2005; 175:2777-82.

[133] Su F, Nguyen ND, Wang Z, Cai Y, Rogiers P, Vincent JL. Fever control in septic shock: Beneficial or harmful? Shock 2005;23:51620.

[134] Pittet JF, Lee H, Morabito D, Howard MB, Welch WJ, Mackersie RC. Serum levels of Hsp 72 measured early after trauma correlate with survival. J Trauma $2002 ; 52: 611-7$.

[135] Ciocca DR, Oesterreich S, Chamness GC, McGuire WL, Fuqua SA. Biological and clinical implications of heat shock protein 27,000 (Hsp27): a review. J Natl Cancer Inst 1993;85:1558-70.

[136] Concannon CG, Gorman AM, Samali A. On the role of Hsp27 in regulating apoptosis. Apoptosis $2003 ; 8: 61-70$.

[137] Niwa M, Hotta K, Hara A, et al. TNF-alpha decreases hsp 27 in human blood mononuclear cells: involvement of protein kinase c. Life Sci 2006 ;80:181-6.

[138] Sheth K, De A, Nolan B, et al. Heat shock protein 27 inhibits apoptosis in human neutrophils. J Surg Res 2001 ;99:129-33.

[139] De AK, Kodys KM, Yeh BS, Miller-Graziano C. Exaggerated human monocyte IL-10 concomitant to minimal TNF-alpha induction by heat-shock protein 27 (Hsp27) suggests Hsp27 is primarily an antiinflammatory stimulus. J Immunol 2000 ;165:3951-8.

[140] Rayner K, Chen YX, McNulty M, et al. Extracellular release of the atheroprotective heat shock protein 27 is mediated by estrogen and competitively inhibits acLDL binding to scavenger receptor-A. Circ Res $2008 ; 103: 133-41$.

[141] Laudanski K, De A, Miller-Graziano C. Exogenous heat shock protein 27 uniquely blocks differentiation of monocytes to dendritic cells. Eur J Immunol 2007;37:2812-24.

[142] Lemieux P, Oesterreich S, Lawrence JA, et al. The small heat shock protein hsp 27 increases invasiveness but decreases motility of breast cancer cells. Invasion Metastasis 1997;17:113-23.

[143] De AK, Roach SE. Detection of the soluble heat shock protein 27 (hsp27) in human serum by an ELISA. J Immunoassay Immunochem 2004;25:159-70.

[144] Korneeva I, Bongiovanni AM, Girotra M, Caputo TA, Witkin SS. Serum antibodies to the $27-\mathrm{kd}$ heat shock protein in women with gynecologic cancers. Am J Obstet Gynecol $2000 ; 183: 18-21$.

[145] Korneeva I, Caputo TA, Witkin SS. Cell-free $27 \mathrm{kDa}$ heat shock protein (hsp27) and hsp27-cytochrome c complexes in the cervix of women with ovarian or endometrial cancer. Int J Cancer 2002 ;2:483-6.

[146] Conroy SE, Sasieni PD, Amin V, et al. Antibodies to heat-shock protein 27 are associated with improved survival in patients with breast cancer. Br J Cancer 1998;77:1875-9.

[147] Thor A, Benz C, Moore D, et al. Stress response protein (srp-27) determination in primary human breast carcinomas: clinical, histologic, and prognostic correlations. J Natl Cancer Inst 1991 ;83:170-8.

[148] Fanelli MA, Cuello Carrion FD, Dekker J, Schoemaker J, Ciocca DR. Serological detection of heat shock protein hsp27 in normal and breast cancer patients. Cancer Epidemiol Biomarkers Prev 1998;7:791-5.

[149] Graner MW, Cumming RI, Bigner DD. The heat shock response and chaperones/heat shock proteins in brain tumors: surface expression, release, and possible immune consequences. J Neurosci $2007 ; 27: 11214-27$.

[150] Benn SC, Perrelet D, Kato AC, et al. Hsp27 upregulation and phosphorylation is required for injured sensory and motor neuron survival. Neuron 2002;36:45-56.

[151] Martin-Ventura JL, Duran MC, Blanco-Colio LM, et al. Identification by a differential proteomic approach of heat shock protein 27 as a potential marker of atherosclerosis. Circulation 2004;110:2216-9.

[152] Miller H, Poon S, Hibbert B, Rayner K, Chen YX, O'Brien ER. Modulation of estrogen signaling by the novel interaction of heat shock protein 27 , a biomarker for atherosclerosis, and estrogen receptor beta: mechanistic insight into the vascular effects of estrogens. Arterioscler Thromb Vasc Biol 2005 ;25:e10-4.

[153] Park HK, Park EC, Bae SW, et al. Expression of heat shock protein 27 in human atherosclerotic plaques and increased plasma level of heat shock protein 27 in patients with acute coronary syndrome. Circulation 2006 ;114:886-93.

[154] Kardys I, Rifai N, Meilhac O, et al. Plasma concentration of heat shock protein 27 and risk of cardiovascular disease: a prospective, nested case-control study. Clin Chem 2008;54:139-46.

[155] Martin-Ventura JL, Nicolas V, Houard X, et al. Biological significance of decreased HSP27 in human atherosclerosis. Arterioscler Thromb Vasc Biol 2006;26:1337-43.

[156] Efthymiou CA, Mocanu MM, de Belleroche J, Wells DJ, Latchmann DS, Yellon DM. Heat shock protein 27 protects the heart against myocardial infarction. Basic Res Cardiol 2004 ;99:392-4.

[157] Schimke I, Lutsch G, Schernes U, et al. Increased level of HSP27 but not of HSP72 in human heart allografts in relation to acute rejection. Transplantation $2000 ; 70: 1694-7$.

[158] De Souza AI, Wait R, Mitchell AG, Banner NR, Dunn MJ, Rose ML. Heat shock protein 27 is associated with freedom from graft vasculopathy after human cardiac transplantation. Circ Res 2005 ;97:192-8.

[159] Ghayour-Mobarhan M, Sahebkar A, Parizadeh SM, et al. Antibody titres to heat shock protein 27 are elevated in patients with acute coronary syndrome. Int J Exp Pathol 2008;89:209-15.

[160] Shams S, Shafi S, Bodman-Smith K, Williams P, Mehta S, Ferns GA. Anti-heat shock protein-27 (Hsp-27) antibody levels in 
patients with chest pain: Association with established cardiovascular risk factors. Clin Chim Acta 2008;395:42-6.

[161] Lucas R, Verin AD, Black SM, Catravas JD. Regulators of endothelial and epithelial barrier integrity and function in acute lung injury. Biochem Pharmacol 2009;77:1763-72.

[162] Salminen A, Paimela T, Suuronen T, Kaarniranta K. Innate immunity meets with cellular stress at the IKK complex: Regulation of the IKK complex by HSP70 and HSP90. Immunol Lett 2008;117:9-15.

[163] Chatterjee A, Black SM, Catravas JD. Endothelial nitric oxide (NO) and its pathophysiologic regulation. Vascul Pharmacol 2008;49:134-40.

[164] Chung SW, Lee JH, Choi KH, et al. Extracellular heat shock protein 90 induces interleukin- 8 in vascular smooth muscle cells. Biochem Biophys Res Commun 2009;378:444-9.

[165] Matthews R, Burnie J. The role of hsp90 in fungal infection. Immunol Today $1992 ; 13: 345-8$.

[166] Matthews R, Hodgetts S, Burnie J. Preliminary assessment of a human recombinant antibody fragment to hsp90 in murine invasive candidiasis. J Infect Dis $1995 ; 171: 1668-71$.

[167] Matthews RC, Rigg G, Hodgett S, et al. Preclinical assessment of the efficacy of mycograb, a human recombinant antibody against fungal HSP90. Antimicrob Agents Chemother 2003;47:2208-16.

[168] Sutherland A, Ellis D. Treatment of a critically ill child with disseminated Candida glabrata with a recombinant human antibody specific for fungal heat shock protein 90 and liposomal amphotericin B, caspofungin, and voriconazole. Pediatr Crit Care Med 2008;9:e23-e5.

[169] Deocaris CC, Kaul SC, Wadhwa R. On the brotherhood of the mitochondrial chaperones mortalin and heat shock protein 60. Cell Stress Chaperones $2006 ; 11: 116-28$.

[170] Ryan MT, Naylor DJ, Hoj PB, Clark MS, Hoogenraad NJ. The role of molecular chaperones in mitochondrial protein import and folding. Int Rev Cytol 1997;174:127-93.

[171] Kol A, Bourcier T, Lichtman AH, Libby P. Chlamydial and human heat shock protein $60 \mathrm{~s}$ activate human vascular endothelium, smooth muscle cells, and macrophages. J Clin Invest 1999 ;103:571-7.

[172] Foteinos G, Afzal AR, Mandal K, Jahangiri M, Xu Q. Anti-heat shock protein 60 autoantibodies induce atherosclerosis in apolipoprotein E-deficient mice via endothelial damage. Circulation $2005 ; 112: 1206-13$.

[173] Xu Q, Willeit J, Marosi M, et al. Association of serum antibodies to heat-shock protein 65 with carotid atherosclerosis. Lancet 1993 ;341:255-9.

[174] Frostegard J, Lemne C, Andersson B, van der Zee R, Kiessling R, de Faire U. Association of serum antibodies to heat-shock protein 65 with borderline hypertension. Hypertension $1997 ; 29: 40-4$.

[175] Hoppichler F, Lechleitner M, Traweger C, et al. Changes of serum antibodies to heat-shock protein 65 in coronary heart disease and acute myocardial infarction. Atherosclerosis 1996 ;126:333-8.

[176] Zhu J, Quyyumi AA, Rott D, et al. Antibodies to human heat-shock protein 60 are associated with the presence and severity of coronary artery disease: evidence for an autoimmune component of atherogenesis. Circulation $2001 ; 103: 1071-5$.

[177] Schett G, Metzler B, Kleindienst R, et al. Myocardial injury leads to a release of heat shock protein (hsp) 60 and a suppression of the anti-hsp65 immune response. Cardiovasc Res. 1999;42:685-95.

[178] Zhang X, He M, Cheng L, et al. Elevated heat shock protein 60 levels are associated with higher risk of coronary heart disease in Chinese. Circulation 2008;118:2687-93.

[179] Mandal K, Afzal AR, Brecker SJ, Poloniecki J, Xu Q, Jahangiri M. Association of serum soluble heat shock protein 60 with toll-like receptor 4 polymorphism and severity of coronary artery disease. Heart 2006;92:683-5.

[180] Lewthwaite J, Owen N, Coates A, Henderson B, Steptoe A. Circulating human heat shock protein 60 in the plasma of British civil servants: relationship to physiological and psychosocial stress. Circulation 2002;106:196-201.

[181] Xu Q, Schett G, Perschinka H, et al. Serum soluble heat shock protein 60 is elevated in subjects with atherosclerosis in a general population. Circulation $2000 ; 102: 14-20$.

[182] Xiao Q, Mandal K, Schett G, et al. Association of serum-soluble heat shock protein 60 with carotid atherosclerosis: clinical significance determined in a follow-up study. Stroke 2005 ;36:2571-6.
[183] Pockley AG, Wu R, Lemne C, Kiessling R, de Faire U, Frostegard J. Circulating heat shock protein 60 is associated with early cardiovascular disease. Hypertension $2000 ; 36: 303-7$.

[184] Wright BH, Corton JM, El-Nahas AM, Wood RF, Pockley AG. Elevated levels of circulating heat shock protein 70 (Hsp70) in peripheral and renal vascular disease. Heart Vessels 2000;15:18-22.

[185] Jamin C, Dugue C, Alard JE, et al. Induction of endothelial cell apoptosis by the binding of anti-endothelial cell antibodies to Hsp60 in vasculitis-associated systemic autoimmune diseases. Arthritis Rheum 2005 ;52:4028-38.

[186] Yokota SI, Hirata D, Minota S, et al. Autoantibodies against chaperonin CCT in human sera with rheumatic autoimmune diseases: comparison with antibodies against other Hsp60 family proteins. Cell Stress Chaperones $2000 ; 5: 337-46$.

[187] Durai M, Gupta RS, Moudgil KD. The T cells specific for the carboxy-terminal determinants of self (rat) heat-shock protein 65 escape tolerance induction and are involved in the regulation of autoimmune arthritis. J Immunol 2004;172:2795-802.

[188] Moudgil KD, Durai M. Regulation of autoimmune arthritis by selfheat-shock proteins. Trends Immunol 2008;29:412-8.

[189] Prakken AB, van Eden W, Rijkers GT, et al. Autoreactivity to human heat-shock protein 60 predicts disease remission in oligoarticular juvenile rheumatoid arthritis. Arthritis Rheum 1996 ;39:1826-32.

[190] Prakken AB, van Hoeij MJ, Kuis W, et al. T-cell reactivity to human HSP60 in oligo-articular juvenile chronic arthritis is associated with a favorable prognosis and the generation of regulatory cytokines in the inflamed joint. Immunol Lett 1997 ;57:139-42.

[191] de Kleer IM, Kamphuis SM, Rijkers GT, et al. The spontaneous remission of juvenile idiopathic arthritis is characterized by $\mathrm{CD} 30+$ $\mathrm{T}$ cells directed to human heat-shock protein 60 capable of producing the regulatory cytokine interleukin-10. Arthritis Rheum 2003 ;48:2001-10.

[192] Quintana FJ, Carmi P, Mor F, Cohen IR. Inhibition of adjuvant arthritis by a DNA vaccine encoding human heat shock protein 60 . J Immunol 2002 Sep 15;169:3422-8.

[193] Quintana FJ, Carmi P, Mor F, Cohen IR. DNA fragments of the human $60-\mathrm{kDa}$ heat shock protein (HSP60) vaccinate against adjuvant arthritis: identification of a regulatory HSP60 peptide. J Immunol 2003;171:3533-41.

[194] Quintana FJ, Carmi P, Cohen IR. DNA vaccination with heat shock protein 60 inhibits cyclophosphamide-accelerated diabetes. J Immunol 2002 Nov 15;169:6030-5.

[195] Wheeler DS, Lahni P, Odoms K, et al. Extracellular heat shock protein 60 (Hsp60) levels in children with septic shock. Inflamm Res 2007;56:216-9.

[196] Vabulas RM, Ahmad-Nejad P, da Costa C, et al. Endocytosed HSP60s use toll-like receptor 2 (TLR2) and TLR4 to activate the toll/interleukin-1 receptor signaling pathway in innate immune cells. J Biol Chem $2001 ; 276: 31332-9$.

[197] Ohashi K, Burkart V, Flohe S, Kolb H. Cutting edge: heat shock protein 60 is a putative endogenous ligand of the toll-like receptor4 complex. J Immunol $2000 ; 164: 558-61$.

[198] Chen W, Syldath U, Bellmann K, Burkart V, Kolb H. Human 60$\mathrm{kDa}$ heat-shock protein: a danger signal to the innate immune system. J Immunol $1999 ; 162: 3212-9$.

[199] Flohe SB, Bruggemann J, Lendemans S, et al. Human heat shock protein 60 induces maturation of dendritic cells versus a Th1promoting phenotype. J Immunol 2003;170:2340-8.

[200] Kilmartin B, Reen DJ. HSP60 induces self-tolerance to repeated HSP60 stimulation and cross-tolerance to other pro-inflammatory stimuli. Eur J Immunol 2004 ;34:2041-51.

[201] Schuchmann M, Hermann F, Herkel J, van der Zee R, Galle PR, Lohse AW. HSP60 and CpG-DNA-oligonucleotides differentially regulate LPS-tolerance of hepatic Kupffer cells. Immunol Lett 2004 ;93:199-204.

[202] Zanin-Zhorov A, Tal G, Shivtiel S, et al. Heat shock protein 60 activates cytokine-associated negative regulator suppressor of cytokine signaling 3 in T cells: effects on signaling, chemotaxis, and inflammation. J Immunol 2005 ;175:276-85.

[203] Osterloh A, Meier-Stiegen F, Veit A, Fleischer B, von Bonin A, Breloer M. Lipopolysaccharide-free heat shock protein 60 activates T cells. J Biol Chem 2004 ;279:47906-11. 
[204] Cohen-Sfady M, Nussbaum G, Pevsner-Fischer M, et al. Heat shock protein 60 activates B cells via the TLR4-MyD88 pathway. J Immunol 2005 Sep 15;175:3594-602.

[205] Hartman DJ, Hoogenraad NJ, Condron R, Hoj PB. Identification of a mammalian $10-\mathrm{kDa}$ heat shock protein, a mitochondrial chaperonin 10 homologue essential for assisted folding of trimeric ornithine transcarbamoylase in vitro. Proc Natl Acad Sci USA 1992 ;89:3394-8.

[206] Quinn KA, Athanasas-Platsis S, Wong TY, Rolfe BE, Cavanagh $\mathrm{AC}$, Morton H. Monoclonal antibodies to early pregnancy factor perturb tumour cell growth. Clin Exp Immunol $1990 ; 80: 100-8$.

[207] Morton H, Cavanagh AC, Athanasas-Platsis S, Quinn KA, Rolfe BE. Early pregnancy factor has immunosuppressive and growth factor properties. Reprod Fertil Dev 1992;4:411-22.

[208] Athanasas-Platsis S, Somodevilla-Torres MJ, Morton H, Cavanagh AC. Investigation of the immunocompetent cells that bind early pregnancy factor and preliminary studies of the early pregnancy factor target molecule. Immunol Cell Biol 2004 ;82:361-9.
[209] Zhang B, Walsh MD, Nguyen KB, et al. Early pregnancy factor treatment suppresses the inflammatory response and adhesion molecule expression in the spinal cord of SJL/J mice with experimental autoimmune encephalomyelitis and the delayed-type hypersensitivity reaction to trinitrochlorobenzene in normal BALB/c mice. J Neurol Sci $2003 ; 212: 37-46$.

[210] Morton H, McKay DA, Murphy RM, et al. Production of a recombinant form of early pregnancy factor that can prolong allogeneic skin graft survival time in rats. Immunol Cell Biol 2000 ;78:603-7.

[211] Johnson BJ, Le TT, Dobbin CA, et al. Heat shock protein 10 inhibits lipopolysaccharide-induced inflammatory mediator production. J Biol Chem $2005 ; 280: 4037-47$.

[212] Malhotra V, Wong HR. Interactions between the heat shock response and the nuclear factor-kappaB signaling pathway. Crit Care Med 2002;30:S89-S95.

[213] Wong HR. Potential protective role of the heat shock response in sepsis. New Horiz 1998;6:194-200.

(C) Giuliano Jr,et al.; Licensee Bentham Open.

This is an open access article licensed under the terms of the Creative Commons Attribution Non-Commercial License (http://creativecommons.org/licenses/by-nc/3.0/) which permits unrestricted, non-commercial use, distribution and reproduction in any medium, provided the work is properly cited. 